\title{
Root form and canal morphology of maxillary first premolars of a Yemeni population
}

\author{
Elham M. Senan ${ }^{1 *}$, Hatem A. Alhadainy ${ }^{2,5}$, Thuraia M. Genaid ${ }^{3}$ and Ahmed A. Madfa1,4
}

\begin{abstract}
Background: The purpose of this study was to investigate variations in the root canal systems of permanent maxillary first premolars in a Yemeni population using a clearing technique.

Methods: Two hundred fifty permanent maxillary first premolar teeth extracted from Yemeni individuals were collected. A small hole in the center of the occlusal surface of each tooth was prepared and pulp tissue was removed by immersion in 5.25\% sodium hypochlorite. Teeth were stored in 5-10\% nitric acid solution for 5-6 days. Next, teeth were rinsed, dried, and dehydrated using ascending concentrations of ethanol (70,95, and 100\%) successively for $12 \mathrm{~h}$ each. Waterproof black ink was injected into the dried dehydrated teeth. Stained teeth were then rendered clear by immersion in methyl salicylate solution (98\%) until evaluation. Root canal morphology of each tooth was then examined.
\end{abstract}

Results: $54.8 \%$ of teeth were single-rooted, while $44.4 \%$ were double-rooted and only $0.8 \%$ had three separated roots. The most common canal system configuration was Vertucci type IV (55.6\%). Eight specimens of the single-rooted premolars (3.2\%) had new canal configurations that have not been recognized in previous published studies. Accessory canals and inter-canal communications were detected in a total of 52.8 and 34.4\% of the specimens, respectively. The apical foramen was located centrally to the apex in $84.9 \%$ and apical deltas were found in $13.2 \%$ of the studied sample.

Conclusions: Yemeni permanent maxillary first premolars are mainly single-rooted and predominantly present Vertucci type IV canal morphology. The finding of additional canal configurations in this study is low but should be kept in mind when performing endodontic therapy for these teeth.

Keywords: Maxillary first premolar, Root canal morphology, Yemeni population, Clearing technique

\section{Background}

Root canal treatment is an essential part of comprehensive, quality dental care [1]. Successful endodontic treatment depends on complete root canal cleansing and shaping, three-dimensional hermetic root canal system obturation, and well-fitting coronal restorations with no leakage [2]. However, lack of thorough knowledge about teeth internal anatomy is one of the main reasons for treatment failure in endodontics. Thus, dental practitioners must be familiar with root canal morphology of teeth to be treated. Such knowledge can aid in localization

\footnotetext{
* Correspondence: elhamdent06@yahoo.com

'Restorative and Prosthodontic Department, College of Dentistry, University of Science and Technology, Sana'a, Yemen

Full list of author information is available at the end of the article
}

and negotiation of canals, as well as their subsequent management [3]. Unfortunately, root canal morphology varies greatly among different populations and even in different individuals within the same population. Therefore, an accurate knowledge of root canal morphology and its anatomical variations is essential for a successful root canal treatment [4].

Maxillary first premolar represents one of the most difficult teeth to be treated endodontically. A number of studies exhibited great variations in root anatomy and root canal morphology [5-13]. These variations in number and type of root canals are probably some of the most widely described anomalies in the literature. The presence of two canals must be considered normal [14, 15], but racial

(C) The Author(s). 2018 Open Access This article is distributed under the terms of the Creative Commons Attribution 4.0 International License (http://creativecommons.org/licenses/by/4.0/), which permits unrestricted use, distribution, and reproduction in any medium, provided you give appropriate credit to the original author(s) and the source, provide a link to the Creative Commons license, and indicate if changes were made. The Creative Commons Public Domain Dedication waiver (http://creativecommons.org/publicdomain/zero/1.0/) applies to the data made available in this article, unless otherwise stated. 
differences in the root canal morphology of maxillary first premolar have been established [14-17].

Numerous studies have dealt with the evaluation of root canal morphology among different populations using various techniques, such as radiographs, decalcification, sectioning, replication and computerized-aided techniques [11-13, 18-21]. Of all these techniques, teeth clearing technique has considerable value in studying the morphology of root canal system. This is because clearing technique provides a three-dimensional view of the pulp cavity in relation to the exterior of teeth and allows a comprehensive examination of the pulp chamber and root canal system [4].

Clinically, it is important to identify the root and canal morphology prevalent in a population to reduce errors during root canal treatment. However, no study in Yemen has yet investigated the incidence of root canal configurations in any tooth. Therefore, the purpose of this study was to evaluate root and canal morphology of permanent maxillary first premolar teeth in a Yemeni population using a clearing technique.

\section{Methods}

The present study was approved by the Medical Ethics Committee (MEC) of Faculty of Medicine and Health Sciences at University of Science and Technology, Sana'a, Yemen (MECA NO.: 2016/13). Two hundred fifty recently extracted maxillary first premolars were collected from Yemeni patients attending various orthodontic clinics in Sana'a city. All teeth were identified at the time of extraction as maxillary first premolars from Yemeni patients attending orthodontic clinics. All patients signed consents acknowledging that their teeth will be used in the study. Teeth sample was collected in one and a half year.

Gender of the patient was not recorded and the age range was 20-45 years. The extracted teeth were thoroughly washed and cleaned to remove blood, saliva, or debris. They were then placed in 5.25\% sodium hypochlorite solution for $30 \mathrm{~min}$ to remove organic debris from the surface. If there was calculus, it was removed using scaler (miniPiezon ${ }^{\circ}$, Electro Medical Systems EMS, Nyon, Switzerland). The cleaned specimens were then saved in 10\% formalin solution (Oxford Laboratory, Mumbai, India) until further investigation was carried out [13].

External root morphology was determined visually and the findings were recorded. The specimens were classified into three groups based on the forms and number of roots as follows: single-rooted, double-rooted and three-rooted premolars. After recording the external root morphology of the specimens, a small hole in the center of the occlusal surface of each tooth was prepared as access to the pulp cavity. The specimens were then immersed in 5.25\% sodium hypochlorite for $4 \mathrm{~h}$ to remove pulpal tissues. They were then rinsed under running tap water for $2 \mathrm{~h}$ and dried overnight. Afterwards, the specimens were decalcified with 10\% nitric acid (Gainlad Chemical Co., Clwyd, UK) for 3 days followed by $5 \%$ nitric acid for 2-3 days at room temperature. The nitric acid solution was changed daily and agitated once a day to speed the process of decalcification. Then, the specimens were tested for softness by inserting a needle into the coronal region [13]. Decalcified specimens were then rinsed thoroughly and stored in water overnight and were bench-dried for $3 \mathrm{~h}$. They were dehydrated in successive solutions of 70, 95 and 100\% ethanol (Scharlau Co., European Union); each for $12 \mathrm{~h}$. Once the dehydration process was completed, teeth were allowed to bench-dry for $2 \mathrm{~h}$.

To clearly view the root canal system, waterproof black ink (Sanford rotring GmbH, Hamburg, Germany) was coronally injected into the pulp chambers using an endodontic irrigation syringe with a 27 gauge needle (BU Kwang Medical Inc., Seoul, Korea) until the ink was seen out through the apical foramen. Excess ink was then removed from the surface of the specimens with gauze soaked in ethanol. The stained specimens were then bench-dried for $4 \mathrm{~h}$. Finally, transparency was achieved by placing the specimens in $98 \%$ methyl salicylate (ACROS Organics, New Jersey, USA).

Standardized pictures of the transparent cleared teeth were obtained by digital photographing both mesio-distally and bucco-lingually with a fixed distance $(10 \mathrm{~cm})$ and zoom $(\times 2.5)$. Photographs were taken with a light-illuminated white paper wet with methyl salicylate solution as a background. Evaluation of cleared teeth images was performed independently by two endodontists, each with an experience of more than five years. This was done after calibration to Vertucci canal types' classification. Inter-examiner agreement was evaluated using Kappa test on SPSS. The following observations were recorded: (i) number and type of root canals; (ii) presence and location of both accessory canals and inter-canal communications (ICCs); (iii) location and number of apical foramina and (iv) presence of apical deltas.

\section{Results \\ Morphology and number of roots}

Of the 250 maxillary first premolars studied, 137 teeth had one root $(54.8 \%)$, whilst $36.4 \%$ were single-tipped root apex and the rest (18.4\%) had double-tipped root apex. Of the 111 (44.4\%) double-rooted premolars, 29.2\% had two separated roots and $15.2 \%$ had two fused roots (they exhibited bifurcation in the apical third). Two premolars of the study sample (0.8\%) had three separated roots (Fig. 1). 


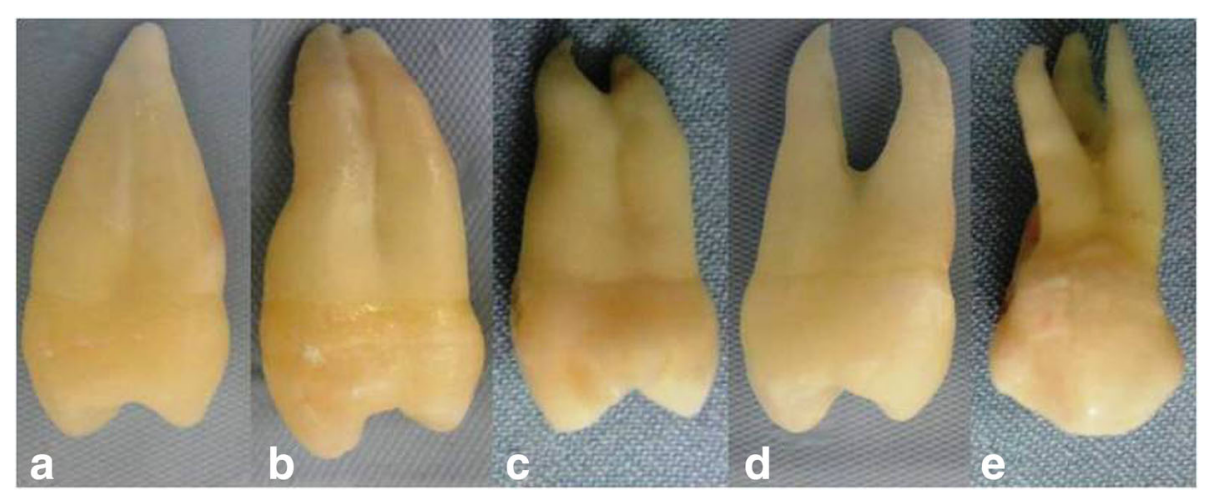

Fig. 1 Clinical photographs showing variations in number of root and morphology in permanent maxillary first premolars.a One root with single tip, (b) one root with double tips, (c) fused two roots, (d) separated two roots and (e) separated three roots

\section{Number and type of root canals}

The data for number and type of root canal system were revealed in Table 1. Single-rooted premolars demonstrated a wide variation of canal configurations (Figs. 2, 3,4). Seventy-four of the single-rooted specimens had one canal (54.1\%) of either Vertucci type I (24.1\%), III (14.6\%), V $(8.8 \%)$ or VII $(6.6 \%)$ configuration, while $35.7 \%(n=49)$ of the specimens had two canals of either type II (8.0\%), IV (24.8\%) or VI (2.9\%) configuration. In addition, four cases of the single-rooted premolars had two canals $(2.9 \%)$ of either Gulabivala type III (2.2\%), or IV (0.7\%) configuration. Furthermore, two cases of the single-rooted premolars had three canals $(1.5 \%)$ of either Gulabivala type I $(0.7 \%)$, or (3-2-1) Sert \& Bayirli (0.7\%) configuration (Table 1). Moreover, eight specimens of the single-rooted premolars had one canal (3.2\%) with new canal configurations that have not been recognized in previous studies (Table 1 , Fig. 4).

On the other hand, the double-rooted specimens exhibited Vertucci types IV and V in 105 (94.6\%) and 2 (1.8\%), respectively (Table 1, Figs. 2 and 3 ). In addition, both Gulabivala type III (1.8\%) and (2-3-2) Sert \& Bayirli (1.8\%) configurations were found in two specimens. Of the three-rooted specimens, both cases exhibited three canals (Table 1, Fig. 2).

\section{Accessory canals, inter-canal communications, apical foramina and deltas}

Accessory canals were detected in a total of 132 (52.8\%) of the specimens (Table 1 ). They were more frequently observed in the apical third as compared to cervical and middle thirds of the roots. Inter-canal communications (ICCs) were present in $86(34.4 \%)$ of the specimens. ICCs were more prevalent in the single-rooted group (25.2\%) compared to the double-rooted $(9.2 \%)$ premolars (Table 1 ). The apical foramen was located centrally to the apex in $84.9 \%$ of the studied sample. Out of all the canals; canals exiting in single foramina were $77.5 \%$; whereas, $19.7 \%$ exited in two separate foramina. Only in $2.8 \%$ of the specimens, three apical foramina were present (Table 2). Apical deltas were found in 33 specimens (13.2\%), of which 29 (11.6\%) were in single-rooted group and 4 (1.6\%) were in double-rooted premolars. However, apical deltas were not detected in the three-rooted premolars (Table 2).

\section{Discussion}

This is the first study in Yemen that evaluated root and canal morphology of permanent maxillary first premolar teeth. Several methods are used to investigate root canal morphology, including root sectioning, modeling, radiographic examination, tooth-clearing technique, cone-beam computed tomography (CBCT) and micro-computed tomography (micro-CT) imaging. Neelakantan et al. [22] compared the efficacy of four tomography methods with digital radiography and a tooth-clearing technique and concluded that only two tomography methods, $\mathrm{CBCT}$ and peripheral quantitative computed tomography, were as accurate as canal staining and tooth-clearing technique in identifying root canal systems. On the other hand, clearing technique was replaced with micro-CT technology which was proven to be the current reference method for the ex vivo study of the root canal anatomy. Micro-CT is preferred upon teeth clearing method due to the significant low detection of Vertucci type I canal in cleared teeth and fine anatomical details when compared to micro-CT method [23]. This limitation of teeth clearing method can be explained by incomplete diffusion of ink dye leading to distorted internal anatomy of cleared teeth and resulting in a different root canal type [23-25]. Although micro-CT has gained popularity because it provides accuracy, high resolution, and can be applied for detailed quantitative and qualitative measurements of the root canal anatomy, micro-CT is not available in all parts of the world, especially underdeveloped and developing countries. Moreover, the cost and radiation dose of micro-CT are other factors. In this study, 
Table 1 The different anatomical features of Yemeni permanent maxillary first premolars

\begin{tabular}{|c|c|c|c|c|}
\hline Features & $\begin{array}{l}\text { Single-rooted } \\
n(\%)\end{array}$ & $\begin{array}{l}\text { Double-rooted } \\
n(\%)\end{array}$ & $\begin{array}{l}\text { Three-rooted } \\
n(\%)\end{array}$ & $\begin{array}{l}\text { Total } \\
n(\%)\end{array}$ \\
\hline \multicolumn{5}{|l|}{ Vertucci classification } \\
\hline Type I (1) & $33(24.1 \%)$ & $0(0.0 \%)$ & $0(0.0 \%)$ & $33(13.2 \%)$ \\
\hline Type II (2-1) & $11(8.0 \%)$ & $0(0.0 \%)$ & $0(0.0 \%)$ & $11(4.4 \%)$ \\
\hline Type III (1-2-1) & $20(14.6 \%)$ & $0(0.0 \%)$ & $0(0.0 \%)$ & $20(8.0 \%)$ \\
\hline Type IV (2) & $34(24.8 \%)$ & $105(94.6 \%)$ & $0(0.0 \%)$ & $139(55.6 \%)$ \\
\hline Type V (1-2) & $12(8.8 \%)$ & $2(1.8 \%)$ & $0(0.0 \%)$ & $14(5.6 \%)$ \\
\hline Type VI (2-1-2) & $4(2.9 \%)$ & $0(0.0 \%)$ & $0(0.0 \%)$ & $4(1.6 \%)$ \\
\hline Type VII (1-2-1-2) & $9(6.6 \%)$ & $0(0.0 \%)$ & $0(0.0 \%)$ & $9(3.6 \%)$ \\
\hline Type VIII (3) & $0(0.0 \%)$ & $0(0.0 \%)$ & $2(100 \%)$ & $2(0.8 \%)$ \\
\hline \multicolumn{5}{|l|}{ Gulabivala classification } \\
\hline Type I (3-1) & $1(0.7 \%)$ & $0(0.0 \%)$ & $0(0.0 \%)$ & $1(0.4 \%)$ \\
\hline Type III (2-3) & $3(2.2 \%)$ & $2(1.8 \%)$ & $0(0.0 \%)$ & $5(2.0 \%)$ \\
\hline Type IV (2-1-2-1) & $1(0.7 \%)$ & $0(0.0 \%)$ & $0(0.0 \%)$ & $1(0.4 \%)$ \\
\hline \multicolumn{5}{|l|}{ Additional types } \\
\hline Type (3-2-1) Sert \& Bayirli & $1(0.7 \%)$ & $0(0.0 \%)$ & $0(0.0 \%)$ & $1(0.4 \%)$ \\
\hline Type (2-3-2) Sert \& Bayirli & $0(0.0 \%)$ & $2(1.8 \%)$ & $0(0.0 \%)$ & $2(0.8 \%)$ \\
\hline \multicolumn{5}{|l|}{ New types } \\
\hline Type (1-2-3) & $2(1.5 \%)$ & $0(0.0 \%)$ & $0(0.0 \%)$ & $2(0.8 \%)$ \\
\hline Type (1-2-1-2-1) & $2(1.5 \%)$ & $0(0.0 \%)$ & $0(0.0 \%)$ & $2(0.8 \%)$ \\
\hline Type (1-2-1-3-2) & $1(0.7 \%)$ & $0(0.0 \%)$ & $0(0.0 \%)$ & $1(0.4 \%)$ \\
\hline Type (1-2-1-2-3-2) & $1(0.7 \%)$ & $0(0.0 \%)$ & $0(0.0 \%)$ & $1(0.4 \%)$ \\
\hline Type (1-3-4) & $1(0.7 \%)$ & $0(0.0 \%)$ & $0(0.0 \%)$ & $1(0.4 \%)$ \\
\hline Type (1-2-1-3-2) & $1(0.7 \%)$ & $0(0.0 \%)$ & $0(0.0 \%)$ & $1(0.4 \%)$ \\
\hline \multicolumn{5}{|l|}{ No. accessory canals } \\
\hline Accessory canals present & $65(47.4 \%)$ & $66(59.5 \%)$ & $1(50 \%)$ & $132(52.8 \%)$ \\
\hline Accessory canals absent & $72(52.6 \%)$ & $45(40.5 \%)$ & $1(50 \%)$ & $118(47.2 \%)$ \\
\hline \multicolumn{5}{|l|}{ Accessory canals in } \\
\hline Cervical third & $4(5.4 \%)$ & $9(11.7 \%)$ & $0(0.0 \%)$ & $13(8.5 \%)$ \\
\hline Middle third & $16(21.6 \%)$ & $29(37.7 \%)$ & $1(50 \%)$ & $46(30.1 \%)$ \\
\hline Apical third & $54(73.0 \%)$ & $39(50.6 \%)$ & $1(50 \%)$ & $94(61.4 \%)$ \\
\hline \multicolumn{5}{|l|}{ No. ICCs } \\
\hline ICCs present & $63(46.0 \%)$ & $23(20.7 \%)$ & $0(0.0 \%)$ & $86(34.4 \%)$ \\
\hline ICCs absent & $74(54.0 \%)$ & $88(79.3 \%)$ & $2(100 \%)$ & $164(65.6 \%)$ \\
\hline \multicolumn{5}{|l|}{ ICCs in } \\
\hline Cervical third & $30(33.0 \%)$ & $13(46.5 \%)$ & $0(0.0 \%)$ & $43(36.2 \%)$ \\
\hline Middle third & 39 (42.9\%) & $9(32.1 \%)$ & $0(0.0 \%)$ & $48(40.3 \%)$ \\
\hline Apical third & $22(24.1 \%)$ & $6(21.4 \%)$ & $0(0.0 \%)$ & $28(23.5 \%)$ \\
\hline
\end{tabular}

canal staining and teeth clearing technique was used as suggested by Peiris [13], to determine the root canal morphology. Apart from being inexpensive and easy to conduct, other important advantages of clearing technique include retaining the original form of the canal, enabling the assessment of canal form and morphology with maintenance of the samples for long time [22].
Root canal morphology has been classified in different ways by several investigators in the literature [4, 26-30]. Weine et al. [26] classification includes four types depending on the pattern of division of the main root canal of a tooth along its course from the floor of the pulp chamber to the root apex. Meanwhile, Vertucci [4] categorized the root canal morphology in a more descriptive manner into 

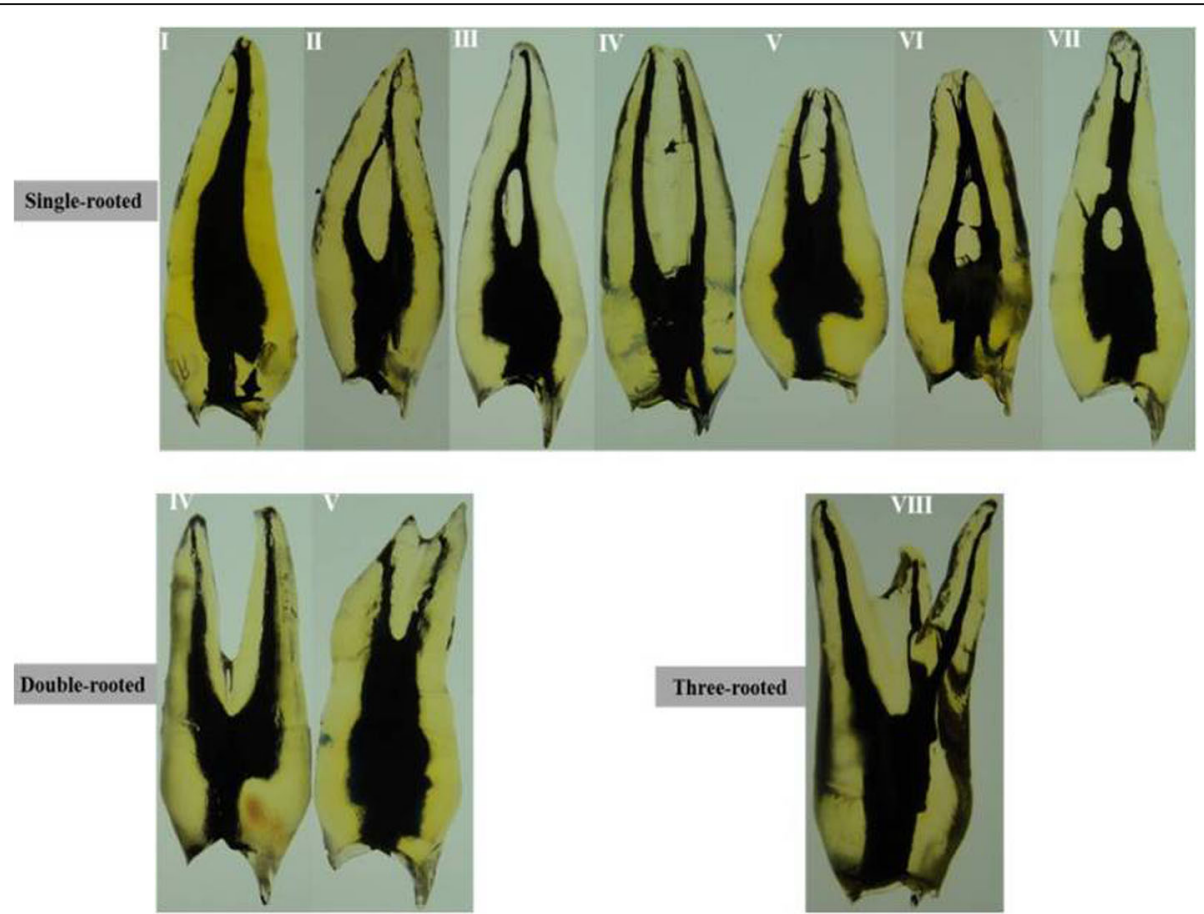

Fig. 2 Cleared teeth demonstrating Vertucci's canal configurations of Yemeni permanent maxillary first premolars
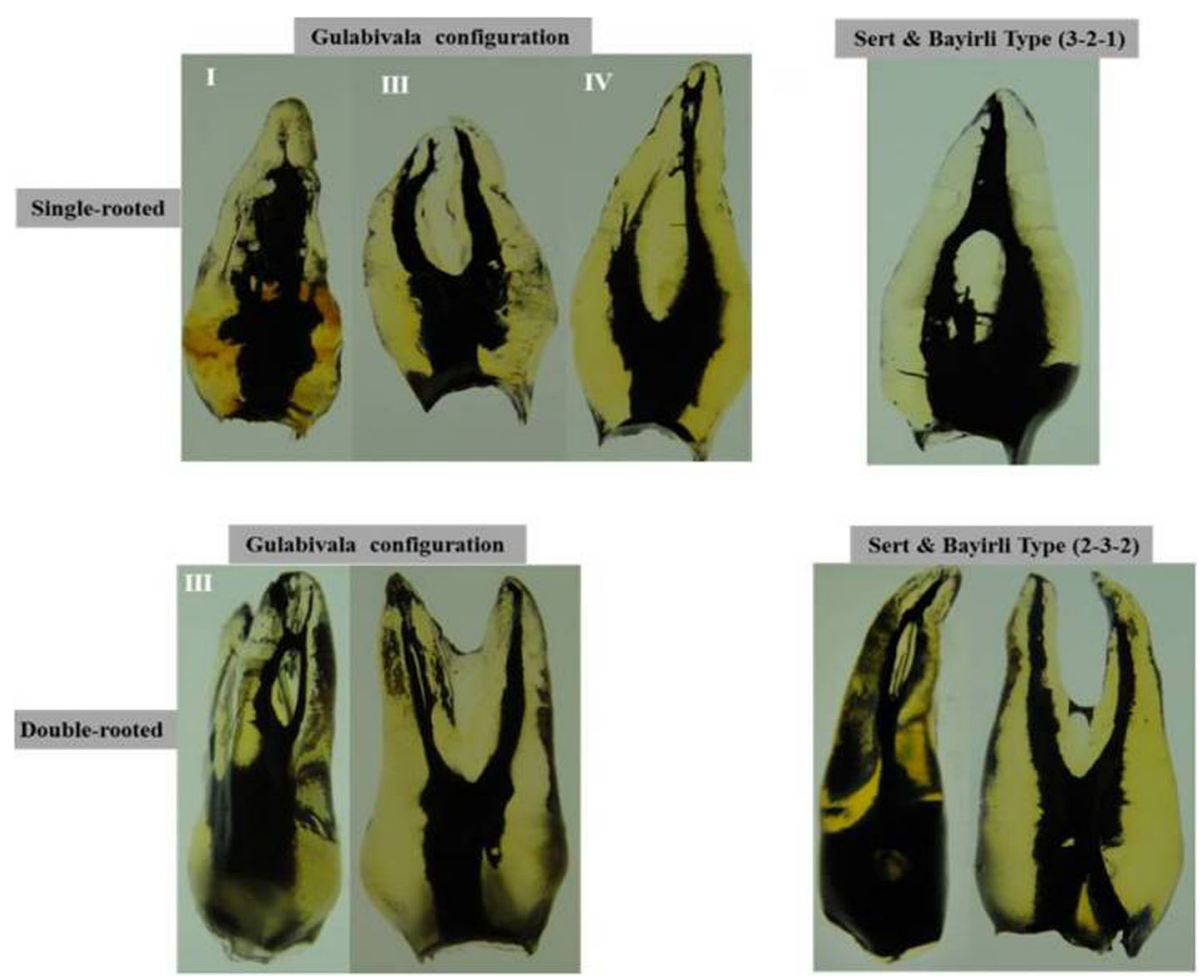

Fig. 3 Cleared teeth demonstrating supplemental canal configurations of Yemeni permanent maxillary first premolars 


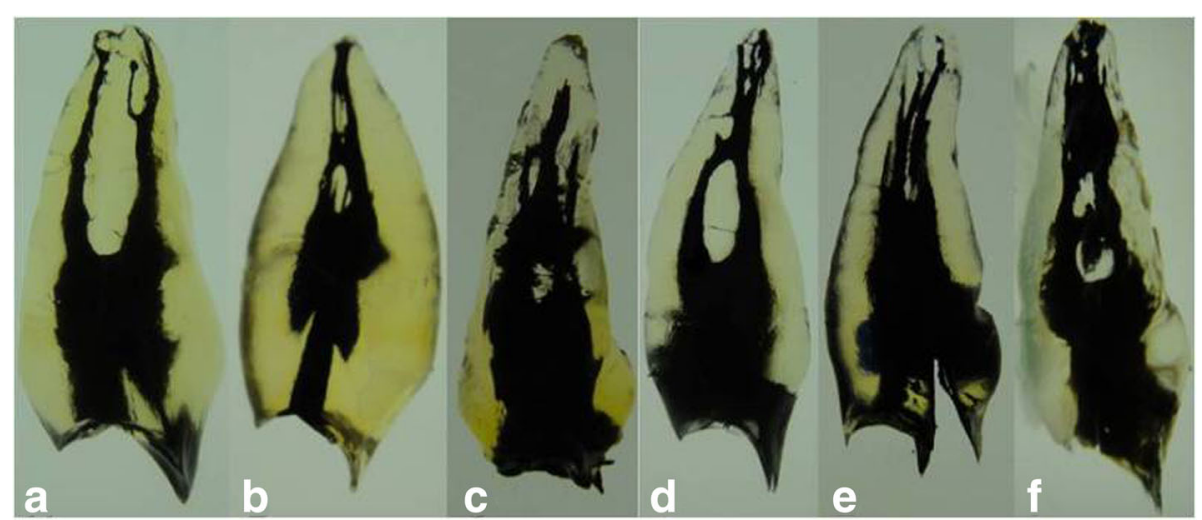

Fig. 4 Cleared teeth showing new canal types of Yemeni permanent maxillary first premolars. a Type (1-2-3), (b) Type (1-2-1-2-1), (c) Type (1-21-3-2), (d) Type (1-2-1-2-3-2), (e) Type (1-3-4), and (f) Type (1-2-1-3-2)

eight types within three main groups. The first group includes three canal types (types I, II, and III), all with one apical foramen. The second one includes four canal types (types IV, V, VI, and VII), all exiting with two apical foramina. The third one includes the last canal type in this classification (type VIII) with three apical foramina. Gulabivala et al. [27, 28] developed two root canal classification systems that were based on observations of root canal configurations within mandibular molars in a sample of Burmese and Thai individuals, respectively. Additional types not present in Vertucci et al. classification were found. A different approach to root canal classification has been offered by Sert and Bayirli [29], who proposed a classification system differentiated by sex on the mandibular and maxillary permanent teeth among Turkish individuals. Fourteen new root canal configurations not included in other previous classification systems were described. Ordinola-Zapata et al. [31] used micro-CT imaging to evaluate of $\mathrm{C}$-shaped mandibular first premolars in a Brazilian subpopulation. They reported several new anatomical variations and complexities of the root canal anatomy that were not included in previous classifications. Ahmed et al. [30, 32, 33] proposed new coding system for classifying root main and accessory canal morphology as well as teeth with anomalies to provide detailed information of the tooth and its root and canal anatomical features. In the present study, Vertucci classification [4] was used as

Table 2 Distribution of apical foramina and deltas of Yemeni permanent maxillary first premolars

\begin{tabular}{|c|c|c|c|c|c|c|c|}
\hline \multirow[t]{2}{*}{ Features } & \multirow{2}{*}{$\begin{array}{l}\text { Single- } \\
\text { rooted } \\
n(\%)\end{array}$} & \multicolumn{2}{|c|}{$\begin{array}{l}\text { Double-rooted } \\
n(\%)\end{array}$} & \multicolumn{3}{|c|}{$\begin{array}{l}\text { Three-rooted } \\
n(\%)\end{array}$} & \multirow[t]{2}{*}{$\begin{array}{l}\text { Total } \\
n(\%)\end{array}$} \\
\hline & & $B$ & P & $\overline{M B}$ & DB & $P$ & \\
\hline \multicolumn{8}{|l|}{ Apical foramen location } \\
\hline Centrally in the apex & $\begin{array}{l}104 \\
(75.9 \%)\end{array}$ & $\begin{array}{l}101 \\
(91.0 \%)\end{array}$ & $\begin{array}{l}99 \\
(89.2 \%)\end{array}$ & $\begin{array}{l}2 \\
(100 \%)\end{array}$ & $\begin{array}{l}2 \\
(100 \%)\end{array}$ & $\begin{array}{l}2 \\
(100 \%)\end{array}$ & $\begin{array}{l}310 \\
(84.9 \%)\end{array}$ \\
\hline Laterally & $\begin{array}{l}17 \\
(12.4 \%)\end{array}$ & $\begin{array}{l}10 \\
(9.0 \%)\end{array}$ & $\begin{array}{l}12 \\
(10.8 \%)\end{array}$ & $\begin{array}{l}0 \\
(0.0 \%)\end{array}$ & $\begin{array}{l}0 \\
(0.0 \%)\end{array}$ & $\begin{array}{l}0 \\
(0.0 \%)\end{array}$ & $\begin{array}{l}39 \\
(10.7 \%)\end{array}$ \\
\hline Both & $\begin{array}{l}16 \\
(11.7 \%)\end{array}$ & $\begin{array}{l}0 \\
(0.0 \%)\end{array}$ & $\begin{array}{l}0 \\
(0.0 \%)\end{array}$ & $\begin{array}{l}0 \\
(0.0 \%)\end{array}$ & $\begin{array}{l}0 \\
(0.0 \%)\end{array}$ & $\begin{array}{l}0 \\
(0.0 \%)\end{array}$ & $\begin{array}{l}16 \\
(4.4 \%)\end{array}$ \\
\hline \multicolumn{8}{|l|}{ No. of apical foramina } \\
\hline One & $\begin{array}{l}61 \\
(44.5 \%)\end{array}$ & $106(95.5 \%)$ & $\begin{array}{l}110 \\
(99.1 \%)\end{array}$ & $2(100 \%)$ & $\begin{array}{l}2 \\
(100 \%)\end{array}$ & $\begin{array}{l}2 \\
(100 \%)\end{array}$ & $\begin{array}{l}283 \\
(77.5 \%)\end{array}$ \\
\hline Two & $\begin{array}{l}66 \\
(48.2 \%)\end{array}$ & $\begin{array}{l}5 \\
(4.5 \%)\end{array}$ & $\begin{array}{l}1 \\
(0.9 \%)\end{array}$ & $\begin{array}{l}0 \\
(0.0 \%)\end{array}$ & $\begin{array}{l}0 \\
(0.0 \%)\end{array}$ & $\begin{array}{l}0 \\
(0.0 \%)\end{array}$ & $\begin{array}{l}72 \\
(19.7 \%)\end{array}$ \\
\hline Three & $\begin{array}{l}10 \\
(7.3 \%)\end{array}$ & $\begin{array}{l}0 \\
(0.0 \%)\end{array}$ & $\begin{array}{l}0 \\
(0.0 \%)\end{array}$ & $\begin{array}{l}0 \\
(0.0 \%)\end{array}$ & $\begin{array}{l}0 \\
(0.0 \%)\end{array}$ & $\begin{array}{l}0 \\
(0.0 \%)\end{array}$ & $\begin{array}{l}10 \\
(2.8 \%)\end{array}$ \\
\hline \multicolumn{8}{|l|}{ Apical deltas } \\
\hline Apical delta present & $\begin{array}{l}29 \\
(21.2 \%)\end{array}$ & $\begin{array}{l}3 \\
(2.7 \%)\end{array}$ & $\begin{array}{l}1 \\
(0.9 \%)\end{array}$ & $\begin{array}{l}0 \\
(0.0 \%)\end{array}$ & $\begin{array}{l}0 \\
(0.0 \%)\end{array}$ & $\begin{array}{l}0 \\
(0.0 \%)\end{array}$ & $\begin{array}{l}33 \\
(13.2 \%)\end{array}$ \\
\hline Apical delta absent & $\begin{array}{l}108 \\
(78.8 \%)\end{array}$ & $\begin{array}{l}108 \\
(97.3 \%)\end{array}$ & $\begin{array}{l}110 \\
(99.1 \%)\end{array}$ & $\begin{array}{l}2 \\
(100 \%)\end{array}$ & $\begin{array}{l}2 \\
(100 \%)\end{array}$ & $\begin{array}{l}2 \\
(100 \%)\end{array}$ & $\begin{array}{l}332 \\
(86.8 \%)\end{array}$ \\
\hline
\end{tabular}


Table 3 In vitro studies on root morphology of the permanent first maxillary premolar

\begin{tabular}{|c|c|c|c|c|c|c|}
\hline Author & Year & Population & $\begin{array}{l}\text { Sample } \\
\text { (n) }\end{array}$ & $\begin{array}{l}\text { Single-rooted } \\
\text { (\%) }\end{array}$ & $\begin{array}{l}\text { Double-rooted } \\
\text { (\%) }\end{array}$ & $\begin{array}{l}\text { Three-rootec } \\
\text { (\%) }\end{array}$ \\
\hline Vertucci \& Gegauff & 1979 & North America & 400 & 39.5 & 56.5 & 4 \\
\hline Walker & 1987 & China & 100 & 60 & 40 & 0 \\
\hline Pecora et al. & 1991 & Brazil & 240 & 55.8 & 41.7 & 2.5 \\
\hline Loh & 1998 & Singapore & 957 & 49.4 & 50.6 & 0 \\
\hline Kartal et al. & 1998 & Turkey & 300 & 37.3 & 61.3 & 1.3 \\
\hline Chaparro et al. & 1999 & Andalusia & 150 & 40 & 56.7 & 3.3 \\
\hline Lipski et al. & 2005 & Poland & 142 & 15.5 & 74 & 9 \\
\hline Atieh & 2008 & Saudia Arabia & 246 & 17.9 & 80.9 & 1.2 \\
\hline Awawdeh et al. & 2008 & Jordan & 600 & 30.8 & 68.4 & 0.8 \\
\hline Present study & - & Yemen & 250 & 54.8 & 44.4 & 0.8 \\
\hline
\end{tabular}

reference because it is the most widely used classification in the literature and is still used in newly published papers $[23,34,35]$. Therefore, for the previous reasons, and also for easier results comparison, it was used in this study. However, additional root canal configurations [27-29] along with Vertucci classification were taken into consideration in this study.

Previous studies of the number of roots in maxillary first premolars showed various results. The prevalence of single-rooted maxillary first premolars (54.8\%) in Yemeni population was in agreement with the findings of Pecora et al. [7], who reported that $55.8 \%$ of their specimens had one root. Walton \& Torabinejad [36] referred to the existence of $50 \%$ of maxillary first premolars with two roots. In the present study, the prevalence of double-rooted premolars was in $44.4 \%$ of the specimens. The prevalence of three-rooted maxillary first premolars $(0.8 \%)$ in this study was consistent with other studies performed in Turkish, Saudi, and Jordanian populations $[8,11,12]$. The number of roots of the maxillary first premolars as reported in previously mentioned studies and studies elsewhere [37-39] is summarized in Table 3 alongside the results of this study.

Vertucci \& Gegauff [5] reported that maxillary first premolar was the only tooth which showed all eight types of Vertucci canal configurations. This was in accordance with this study in which all eight types of Vertucci canal configurations were found. In addition, in the current study, $2.8 \%$ of premolars showed types I, III, and IV of Gulabivala $[27,28]$ canal configurations, and $1.2 \%$ of Sert \& Bayirli [29] additional canal types. More interesting findings of this study were the new root canal configurations found in eight premolars (3.2\%). Although these canal types represent a low percentage but their treatment is challenging. Table 4 summarizes the percentage of root canal configurations in maxillary first premolars reported in previous studies [8, 10-13, 37-39] along with the results of the present study.

Table 4 In vitro studies on root canal configuration of the permanent first maxillary premolar

\begin{tabular}{|c|c|c|c|c|c|c|c|c|c|c|c|c|}
\hline \multirow[t]{2}{*}{ Author } & \multirow[t]{2}{*}{ Year } & \multirow[t]{2}{*}{ Population } & \multirow{2}{*}{$\begin{array}{l}\text { Sample } \\
\text { (n) }\end{array}$} & \multicolumn{8}{|c|}{ Vertucci's root canal configuration (\%) } & \multirow{2}{*}{$\begin{array}{l}\text { Additional } \\
\text { types (\%) }\end{array}$} \\
\hline & & & & I & $\|$ & III & IV & V & $\mathrm{VI}$ & VII & VIII & \\
\hline Vertucci \& Gegauff & 1979 & North America & 400 & 8 & 18 & - & 62 & 7 & - & - & 5 & - \\
\hline Caliskan et al. & 1995 & Turkey & 100 & 3.9 & 5.9 & - & 78.4 & 5.9 & 5.9 & - & - & - \\
\hline Kartal et al. & 1998 & Turkey & 300 & 8.7 & 1 & - & 71.3 & 14.7 & 2.3 & 0.3 & 1.3 & - \\
\hline Chaparro et al. & 1999 & Andalusia & 150 & 1.3 & 37.3 & - & 58 & - & - & - & 3.3 & - \\
\hline Sert \& Bayirli & 2004 & Turkey & 200 & 10.5 & 12.5 & 5.5 & 61.5 & 3.5 & 1 & - & 3 & - \\
\hline Lipski et al. & 2005 & Poland & 142 & 2.1 & 6.3 & - & 82.4 & - & - & - & 9.2 & - \\
\hline \multirow[t]{2}{*}{ Peiris $^{a}$} & 2008 & Sri Lanka & 153 & 1.3 & 16.3 & 2 & 64 & 5.9 & 5.9 & 0.7 & - & 3.9 \\
\hline & 2008 & Japan & 81 & 4.9 & 29.6 & 2.5 & 45.7 & 2.5 & 8.6 & - & - & 6.2 \\
\hline Atieh & 2008 & Saudia Arabia & 246 & 8.9 & 26.8 & - & 63 & - & - & - & 1.2 & - \\
\hline Awawdeh et al. & 2008 & Jordan & 600 & 3.3 & 10.2 & 0.3 & 79.7 & 2 & 2.3 & - & 1.5 & 0.7 \\
\hline Weng et al. & 2009 & China & 95 & 6.3 & 22.1 & 3.2 & 64.2 & 3.2 & 1 & - & - & - \\
\hline Present study & - & Yemen & 250 & 13.2 & 4.4 & 8.0 & 55.6 & 5.6 & 1.6 & 3.6 & 0.8 & 7.2 \\
\hline
\end{tabular}

${ }^{\mathrm{a}}$ This study was performed in a Sri Lankan and Japanese populations 
Table 5 In vitro studies on root canal morphology (accessory canals, inter-canal communications, apical foramina, deltas) of the permanent first maxillary premolar

\begin{tabular}{|c|c|c|c|c|c|c|c|c|}
\hline \multirow[t]{2}{*}{ Author } & \multirow[t]{2}{*}{ Year } & \multirow[t]{2}{*}{ Population } & \multirow{2}{*}{$\begin{array}{l}\text { Sample } \\
\text { (n) }\end{array}$} & \multirow{2}{*}{$\begin{array}{l}\text { Accessory } \\
\text { Canals } \\
\text { (\%) }\end{array}$} & \multirow{2}{*}{$\begin{array}{l}\text { ICCS } \\
\text { (\%) }\end{array}$} & \multicolumn{2}{|c|}{ Apical Foramina } & \multirow{2}{*}{$\begin{array}{l}\text { Deltas } \\
\text { (\%) }\end{array}$} \\
\hline & & & & & & $\begin{array}{l}\text { Central } \\
\text { (\%) }\end{array}$ & $\begin{array}{l}\text { Lateral } \\
\text { (\%) }\end{array}$ & \\
\hline Vertucci \& Gegauff & 1979 & North America & 400 & $49.5^{a}$ & 34.2 & 12 & $88^{a}$ & 3.2 \\
\hline Caliskan et al. & 1995 & Turkey & 100 & 33.3 & 17.7 & 33.3 & 66.7 & 21.6 \\
\hline Kartal et al. & 1998 & Turkey & 300 & 26 & 7 & 15.3 & 84.7 & 7.7 \\
\hline Sert \& Bayirli & 2004 & Turkey & 200 & 33 & 12 & 34 & 76 & 30.7 \\
\hline Awawdeh et al. & 2008 & Jordan & 600 & 19.3 & 7 & 60 & 40 & 4.3 \\
\hline Weng et al. & 2009 & China & 95 & 51.7 & - & - & - & - \\
\hline Present study & - & Yemen & 250 & 52.8 & 34.4 & 84.9 & 15.1 & 13.2 \\
\hline
\end{tabular}

aPercentage is from canals number (788) not teeth number

The occurrence of accessory canals in this study was $52.8 \%$ with maximum number noticed in the apical third (37.6\%) of the roots. This was in accordance with text book of endodontics, where the highest incidence of accessory canals was found in the apical third of the root [40]. Different investigators [5, 8, 12, 29, 38, 39] have reported variations in the prevalence of accessory canals in maxillary first premolars (Table 5).

Inter-canal communications (ICCs) or transverse anastomoses/isthmuses were present in $34.4 \%$ of the specimens with highest percentage being in the middle third of the root (19.2\%). This was in agreement with textbook of endodontics, where highest incidence of ICCs was found in the middle third of the root [40]. An isthmus is a narrow, ribbon-shaped communication between two root canals that contains pulp or pulpally derived tissue. It functions as a bacterial reservoir. This communication is of clinical significance as it may be difficult to debride and fill adequately [41, 42]. The prevalence of ICCs in maxillary first premolars as reported in studies elsewhere $[5,8,12,29,38]$ is summarized in Table 5 alongside the results of this study.

The location of apical foramen is of clinical significance during working length determination, which often depends on the average position of the apical constriction relative to the root apex $[41,42]$. In the present study, the apical foramen was found to be central in $84.9 \%$ of the studied specimens. This is much higher than previous studies that showed that the apical foramen was centrally-located in 12 to $60 \%$ of their specimens (Table 5). The low percentage of laterally-located apical foramina in this study in comparison to other studies may be due to ethnicity. In addition, teeth used in the present study were collected from young patients attending orthodontic clinics. Obviously, age would mostly affect apical foramina location due to deposition of secondary dentine within the root canal that moves the site of the apical constriction away from the apex. These may explain why in this study the apical foramina were centrally-located in most studied specimens compared to previous studies $[5,8,12,29,38]$ (Table 5). Apical deltas were observed in $13.2 \%$ of the collected Yemeni maxillary first premolars. The incidence of apical deltas in the maxillary first premolar as reported in previous studies $[5,8$, $12,29,38]$ is summarized in Table 5 alongside the findings of this study.

\section{Conclusion}

Yemeni permanent maxillary first premolars are mainly single-rooted and predominantly present type IV Vertucci canal morphology. The finding of additional canal configurations in this study is low but should be kept in mind when performing endodontic therapy for these teeth. The results of the present study further confirm the importance of a thorough knowledge of root canal morphology for each population and the need of a careful exploration and radiographic examination of these teeth prior to endodontic therapy.

\section{Abbreviations}

CBCT: cone-beam computed tomography; ICCs: Inter-canal communications; MEC: Medical Ethics Committee; micro-CT: micro-computed tomography

\section{Acknowledgements}

The authors would like to acknowledge the co-operation received from the staff of the orthodontic clinics from where the teeth sample for this study was collected.

\section{Funding}

This study was entirely funded by University of Science and Technology, Sana'a, Yemen.

\section{Availability of data and materials}

The data analyzed during the current study are available from the corresponding author on request.

\section{Authors' contributions}

ES contributed with research concept, sample collection, technical steps, data collection, statistical analysis, writing the original draft and reviewing and editing the final manuscript. HA contributed with research concept, supervision, sample evaluation, statistical analysis, writing the original draft and critical reviewing and editing of the final manuscript. TG contributed with supervision and writing the original draft. AM contributed with statistical analysis, writing the original draft and 
reviewing and editing the final manuscript. All authors read and approved the final manuscript

\section{Authors' information}

ES is a Lecturer of Endodontics at the Restorative and Prosthodontic Department, College of Dentistry, University of Science and Technology, Sana'a, Yemen.

$\mathrm{HA}$ is a Professor of Endodontics and a visiting professor at University of Alberta, Canada, on leave from the Department of Endodontics, Faculty of Dentistry, Tanta University, Tanta, Egypt.

TG is a Professor of Conservative Dentistry at the Department of Conservative Dentistry, Faculty of Dentistry, Tanta University, Tanta, Egypt. AM is an Associate Professor of Endodontics at the Department of Conservative Dentistry, Faculty of Dentistry, Thamar University, Dhamar, Yemen, and at the Restorative and Prosthodontic Department, College of Dentistry, University of Science and Technology, Sana'a, Yemen.

\section{Ethics approval and consent to participate}

The present study was approved by the Medical Ethics Committee of Faculty of Medicine and Health Sciences at University of Science and Technology, Sana'a, Yemen (MECA NO.: 2016/13). All patients signed consents acknowledging that their teeth will be used in the study.

\section{Competing interests}

The authors declare that they have no competing interests.

\section{Publisher's Note}

Springer Nature remains neutral with regard to jurisdictional claims in published maps and institutional affiliations.

\section{Author details}

${ }^{1}$ Restorative and Prosthodontic Department, College of Dentistry, University of Science and Technology, Sana'a, Yemen. '2Department of Dentistry, University of Alberta, Edmonton, Canada. ${ }^{3}$ Department of Conservative Dentistry, Faculty of Dentistry, Tanta University, Tanta, Egypt. ${ }^{4}$ Department of Conservative Dentistry, Faculty of Dentistry, Thamar University, Dhamar, Yemen. ${ }^{5}$ Department of Endodontics, Faculty of Dentistry, Tanta University, Tanta, Egypt.

Received: 14 October 2016 Accepted: 22 May 2018

Published online: 31 May 2018

\section{References}

1. Lai W-H, Ho S-C, Weng T-Y, Huang S-T. Profile of nonsurgical root canal treatment under the National Health Insurance in Taiwan in 2006. J Dent Sci. 2009;4:187-90.

2. Chen $\mathrm{G}$, Chang Y-C. Effects of liquid- and paste-type EDTA on smear-layer removal during rotary root-canal instrumentation. J Dent Sci. 2011;6:41-7.

3. Awawdeh $\mathrm{LA}$, Al-Qudah AA. Root form and canal morphology of mandibular premolars in a Jordanian population. Int Endod J. 2008;41:240-8.

4. Vertucci FJ. Root canal anatomy of the human permanent teeth. Oral Surg Oral Med Oral Pathol. 1984;58:589-99.

5. Vertucci FJ, Gegauff A. Root canal morphology of the maxillary first premolar. J Am Dent Assoc. 1979:99:194-8.

6. Walker RT. Root form and canal anatomy of maxillary first premolars in a southern Chinese population. Dent Traumatol. 1987;3:130-4.

7. Pecora JD, Saquy PC, SousaNeto MD, Woelfel JB. Root form and canal anatomy of maxillary first premolars. Braz Dent J. 1991;2:87-94

8. Kartal N, Ozcelik B, Cimilli H. Root canal morphology of maxillary premolars. J Endod. 1998:24:417-9.

9. Loh HS. Root morphology of the maxillary first premolar in Singaporeans. Aust Dent J. 1998:43:399-402

10. Lipski M, Woźniak K, Łagocka R, Tomasik M. Root and canal morphology of the human maxillary first premolar. Durham Anthropol J. 2005;12:2-3.

11. Atieh MA. Root and canal morphology of maxillary first premolars in a Saudi population. J Contemp Dent Pract. 2008;9:46-53.

12. Awawdeh $L A$, Abdullah $H, A l-Q u d a h ~ A A$. Root form and canal morphology of Jordanian maxillary first premolars. J Endod. 2008;34:956-61.

13. Peiris R. Root and canal morphology of human permanent teeth in a Sri Lankan and Japanese population. Anthropol Sci. 2008;116:123-33.
14. Neelakantan P, Subbarao C, Ahuja R, Subbarao CV. Root and cana morphology of Indian maxillary premolars by a modified root canal staining technique. Odontology. 2011;99:18-21.

15. Koçani F, Kamberi B, Dragusha E, Kelmendi T, Sejfija Z. Correlation between anatomy and root canal topography of first maxillary premolar on kosovar population. Open J Stomatol. 2014:4:332-9.

16. Trope M, Elfenbein L, Trondstad L. Mandibular premolars with more than one root canal in different race groups. J Endod. 1986;12:343-5.

17. Sieraski SM, Taylor GN, Kohn RA. Identification and endodontic management of three-canaled maxillary premolars. J Endod. 1989;5:29-32.

18. Mayo CV, Montgomery S, Rio C. A computerized method for evaluating root canal morphology. J Endod. 1986;12:2-7.

19. Baurmann M. A new approach to demonstration of root canal anatomy. J Dent Educ. 1994;28:704-8.

20. Blaskovic-Subat V, Smojver I, Maricic D, Sutaalo J. A computerized method for the evaluation of root canal morphology. Int Endod J. 1995;28:290-6.

21. Omer OE, Ai Shalabi RM, Jennings M, Glennon J, Claffey NM. A comparison between clearing and radiographic techniques in the study of the root-canal anatomy of maxillary first and second molars. Int Endod J. 2004;37:291-7.

22. Neelakantan P, Subbarao C, Subbarao CV. Comparative evaluation of modified canal staining and clearing technique, cone-beam computed tomography, peripheral quantitative computed tomography, spiral computed tomography and plain and contrast medium-enhanced digital radiography in studying root canal morphology. J Endod. 2010;36:1547-51.

23. Ordinola-Zapata R, Bramante CM, Versiani MA, Moldauer BI, Topham G, Gutmann JL, Nuñez A, Duarte MA, Abella F. Comparative accuracy of the clearing technique, $C B C T$ and micro-CT methods in studying the mesial root canal configuration of mandibular first molars. Int Endod J. 2017;50:90-6.

24. Kim Y, Perinpanayagam H, Lee JK, Yoo YJ, Oh S, Gu Y, Lee SP, Chang SW, Lee W, Baek SH, Zhu Q. Comparison of mandibular first molar mesial root canal morphology using micro-computed tomography and clearing technique. Acta Odonto Scandi. 2015;73:427-32.

25. Lee KW, Kim Y, Perinpanayagam H, Lee JK, Yoo YJ, Lim SM, Chang SW, Ha $\mathrm{BH}$, Zhu Q, Kum KY. Comparison of alternative image reformatting techniques in micro-computed tomography and tooth clearing for detailed canal morphology. J Endod. 2014;40:417-22.

26. Weine FS, Healey HJ, Gerstein H, Evanson L. Canal configuration in the mesiobuccal root of the maxillary first molar and its endodontic significance. Oral Surg Oral Med Oral Pathol. 1969;28:419-25.

27. Gulabivala K, Aung TH, Alavi A, Ng YL. Root and canal morphology of Burmese mandibular molars. Int Endod J. 2001;34:359-70.

28. Gulabivala K, Opasanon A, Ng YL, Alavi A. Root and canal morphology of Thai mandibular molars. Int Endod J. 2002;35:56-62.

29. Sert S, Bayirli GS. Evaluation of the root canal configurations of the mandibular and maxillary permanent teeth by gender in the Turkish population. J Endod. 2004;30:391-8.

30. Ahmed HM, Versiani MA, De-Deus G, Dummer PM. A new system for classifying root and root canal morphology. Int Endodo J. 2017;50:761-70.

31. Ordinola-Zapata R, Monteiro Bramante C, Gagliardi Minotti P, Cavalini Cavenago B, Gutmann JL, Moldauer BI, Versiani MA, Duarte H. Micro-CT evaluation of C-shaped mandibular first premolars in a Brazilian subpopulation. Int Endod J. 2015:48:807-13.

32. Ahmed HM, Neelakantan P, Dummer PM. A new system for classifying accessory canal morphology. Int Endod J. 2018:51:164-76.

33. Ahmed HM, Dummer PM. A new system for classifying tooth, root and canal anomaly. Int Endod J. 2017;12 In Press

34. Mokhtari H, Niknami M, Zonouzi HR, Sohrabi A, Ghasemi N, Golzar AA. Accuracy of cone-beam computed tomography in determining the root canal morphology of mandibular first molars. Iran Endod J. 2016;11:101-5.

35. Akhlaghi NM, Khalilak Z, Vatanpour M, Mohammadi S, Pirmoradi S, Fazlyab M, Safavi K. Root canal anatomy and morphology of mandibular first molars in a selected Iranian population: an in vitro study. Iran Endod J. 2017;12:87-91.

36. Walton R, Torabinenjad M. Principles and Practice of Endodontics. 2nd ed. Philadelphia: W.B. Saunders Co; 1996. p. 177-8.

37. Chaparro AJ, Segura JJ, Guerrero E, Jiménez-Rubio A, Murillo C, Fetio JJ. Number of roots and canals in maxillary first premolars: study of an Andalusian population. Dent Traumatol. 1999;15:65-7.

38. Caliskan MK, Pehlivan Y, Sepetcioglu F, Turkun M, Tuncer SS. Root canal morphology of human permanent teeth in a Turkish population. J Endod. 1995;21:200-4. 
39. Weng XL, Yu SB, Zhao SL, Wang HG, Mu T, Tang RY, Zhou XD. Root canal morphology of permanent maxillary teeth in the Han nationality in Chinese Guanzhong area: a new modified root canal staining technique. J Endod. 2009:35:651-6.

40. Hargreaves KM, Cohen S. Pathways of the pulp, vol. 139. 10th ed. Louis Missouri: CV Mosby; 2011.

41. Weine FS. The enigma of the lateral canal. Dent Clin N Am. 1984;28:833-52.

42. Vertucci FJ. Root canal morphology and its relationship to endodontic procedures. Endod Topics. 2005;10:3-29.

Ready to submit your research? Choose BMC and benefit from:

- fast, convenient online submission

- thorough peer review by experienced researchers in your field

- rapid publication on acceptance

- support for research data, including large and complex data types

- gold Open Access which fosters wider collaboration and increased citations

- maximum visibility for your research: over $100 \mathrm{M}$ website views per year 